\title{
Chapter 10 \\ Developing and Trialing a System to Monitor Radionuclides in Individual Plots of Farmland to Help Reconstruction Farming in Contaminated Areas
}

\author{
Toshiyuki Monma, Puangkaew Lurhathaiopath, Youichi Kawano, \\ Dambii Byambasuren, Yuta Ono, and Quar Evine
}

\begin{abstract}
We believe that if Fukushima Prefecture's agriculture is to be saved, it is essential to create and effectively utilize a system for monitoring the radioactive contamination in each individual parcel of farmland. We are therefore currently developing such a system, as well as a mechanism for putting it to practical use, in the heavily contaminated Tamano district of Soma, adjacent to the village of Iitate. In this chapter, we describe the research outcomes verified to date relating to the characteristics and applications of the monitoring system we are developing.
\end{abstract}

Keywords Radioactive contamination • Radioactive substance monitoring system - Decontamination

\footnotetext{
T. Monma $(\triangle) \cdot \mathrm{D}$. Byambasuren

Department of International Biobusiness Studies, Tokyo University of Agriculture,

1-1-1 Sakuragaoka, Setagaya-ku, Tokyo 156-8502, Japan

e-mail: monma@nodai.ac.jp

P. Lurhathaiopath

Faculty of Life and Environmental Sciences, Tsukuba University,

1-1-1 Tennodai, Tsukuba City, Ibaraki Prefecture 305-8577, Japan

Y. Kawano

Department of Agro-Environmental Science, Obihiro University of Agriculture and Veterinary Medicine, 11 Nishi2sen Inadamachi, Obihiro-shi, Hokkaido 080-8555, Japan

Y. Ono $\bullet$ Q. Evine

Graduate School of Agriculture, Tokyo University of Agriculture,

1-1-1 Sakuragaoka, Setagaya-ku, Tokyo 156-8502, Japan
} 


\subsection{Extent of Radioactive Contamination}

Some of the earliest research conducted in areas contaminated by the Fukushima nuclear disaster entailed monitoring the distribution of ambient radiation doses and the extent to which the soil had been contaminated. Initially, there were a large number of researchers gathering a variety of measurements, but gradually such measurements came to be released by the administrative authorities, and the independent research was discontinued. The public bodies representing the administrative authorities reported radioactive contamination in each area as shown in Figs. 10.1 and 10.2. Thanks to the release of such data, residents in the disaster zones and the Japanese public in general were able to understand the actual risk presented to them by radiation and take appropriate defensive measures themselves.

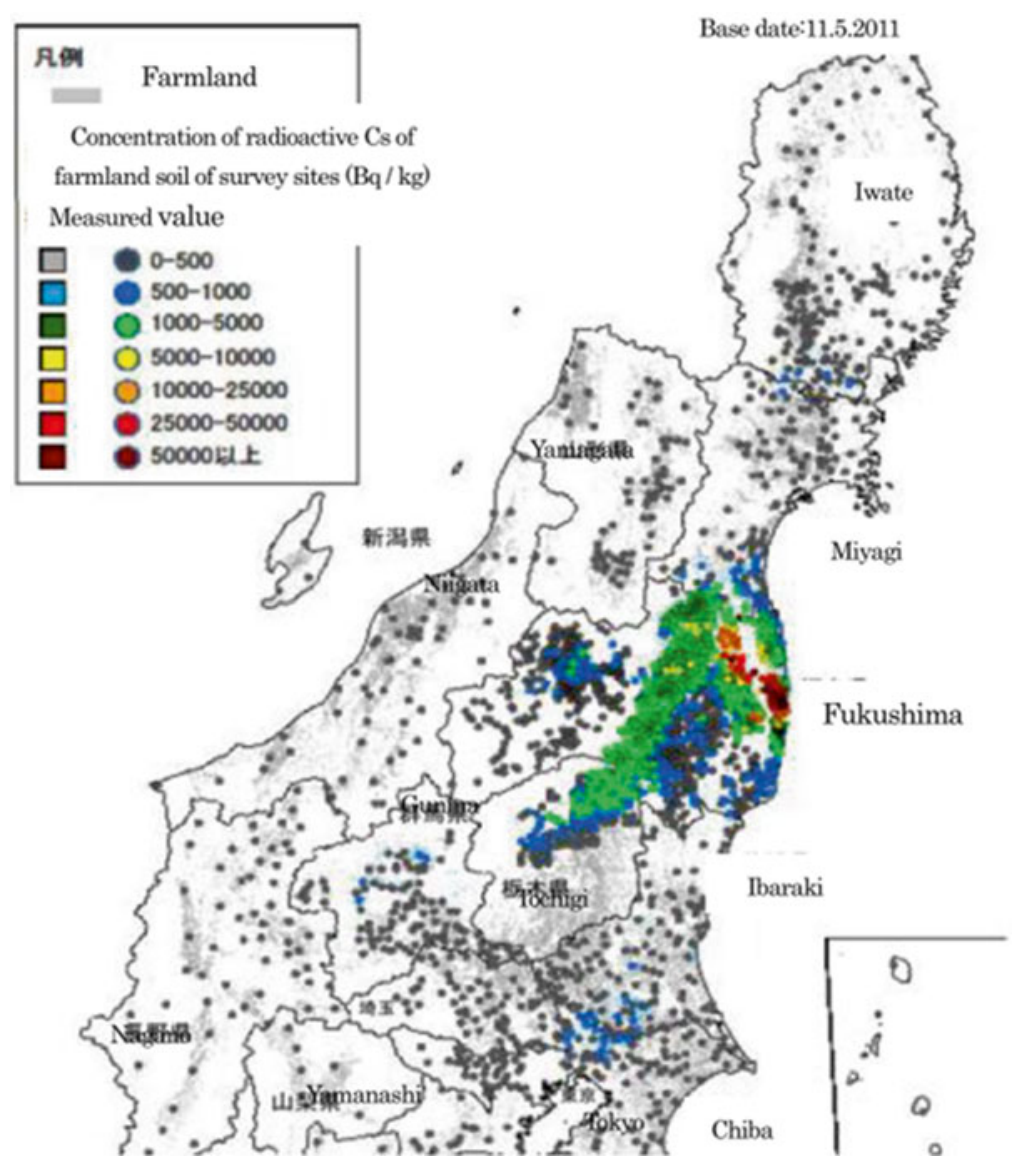

Fig. 10.1 Concentrations of radioactive cesium in farmland soil in the Kanto and Tohoku region 


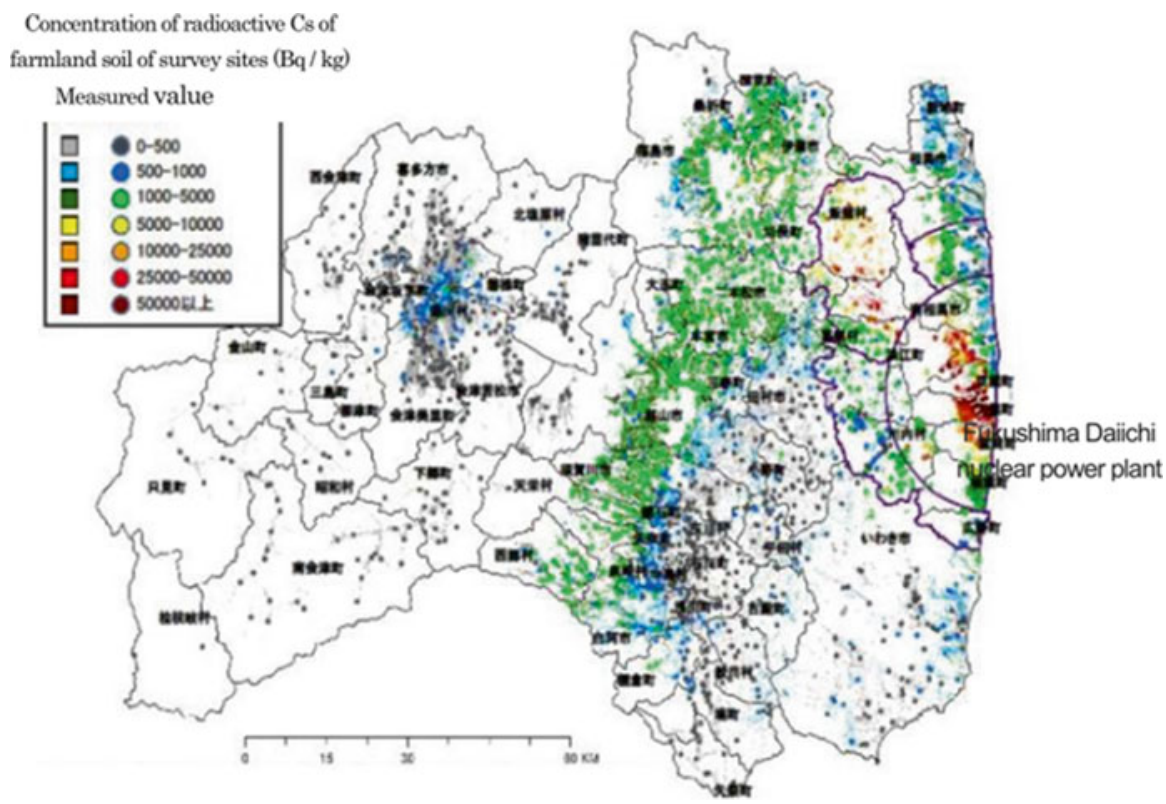

Fig. 10.2 Concentrations of radioactive cesium in farmland soil in Fukushima Prefecture

The results of these surveys indicated that areas around the Fukushima Daiichi Nuclear Power Station and to the northwest of it were severely contaminated by radiation. At the same time, damage was also found in many other areas including the Aizu Basin; the southern part of Miyagi Prefecture near the border with Fukushima Prefecture; along the border between Iwate and Miyagi Prefectures; northern Tochigi Prefecture; areas around the borders of Ibaraki, Chiba, and Saitama Prefectures; and northern Gunma Prefecture.

\subsection{The Importance of a Radioactive Substance Monitoring System in Handling Radioactive Contamination and Reconstructing Agriculture}

There are three important issues in response to radioactive contamination: the first is compensation for damage incurred, the second is decontamination of the living environment, and the third is decontamination of the agricultural and forestry production bases. This chapter focuses on the last two issues, relating to decontamination.

Decontamination of the living environment is currently under way to lower ambient radiation doses, so that accumulated doses do not exceed an annual level of $1 \mathrm{mSv}$ and people can live safely in the areas affected. However, decontamination 
that focuses mainly on the areas where people live and work cannot lower the overall ambient radiation dose in regions where radionuclides are scattered over a wide area.

The agricultural and forestry industry production bases that require decontamination include paddy fields, non-paddy arable fields, pastures, and forests. It is important to note that agriculture and forestry are the main industries in the areas contaminated by radiation. If the recovery of these industries is delayed by the contamination incurred, not only will this cause the industries themselves to decline locally, but it will also exert a major impact on people's lives and the conservation of the natural environment in the areas affected.

Although rehabilitation of agriculture and forestry in the contaminated areas is an urgent issue, the national government has been slow to respond, faced as it is with the need to allocate huge budgets for decontamination and compensation. Meanwhile, the agricultural and forestry industries in these areas are on the verge of a crisis because of a whole array of factors including the contamination itself, the damage caused by negative reputation, the evacuation of farmers to other locations, and the outflow of young people from the remaining habitable areas.

At Tokyo University of Agriculture, we believe that if Fukushima Prefecture's agriculture is to be saved, it is essential to create and effectively utilize a system for monitoring the radioactive contamination in each individual parcel of farmland. We are therefore currently developing such a system, as well as a mechanism for putting it to practical use, in the heavily contaminated Tamano district of Soma, adjacent to the village of Iitate.

In this chapter, we describe the research outcomes verified to date relating to the characteristics and applications of the monitoring system we are developing.

\subsection{The Purpose of Developing a Radioactive Substance Monitoring System}

Three factors explain why radioactive contamination is severely inhibiting recovery in agriculture and forestry.

1. Delay in understanding the extent of the radioactive contamination in farmlands, forests, and elsewhere: Although a more detailed map of ambient radiation doses has now been created based on grid units, the extent to which radioactive contamination has spread within soil, forests, and timber is still not fully understood (Fig. 10.3).

2. Unease regarding the methods used to remove radionuclides and the effectiveness of the removal. The challenges of decontaminating extensive farmlands where radionuclide have accumulated are compounded by residents' increasing doubts about the efficacy of the decontamination. 


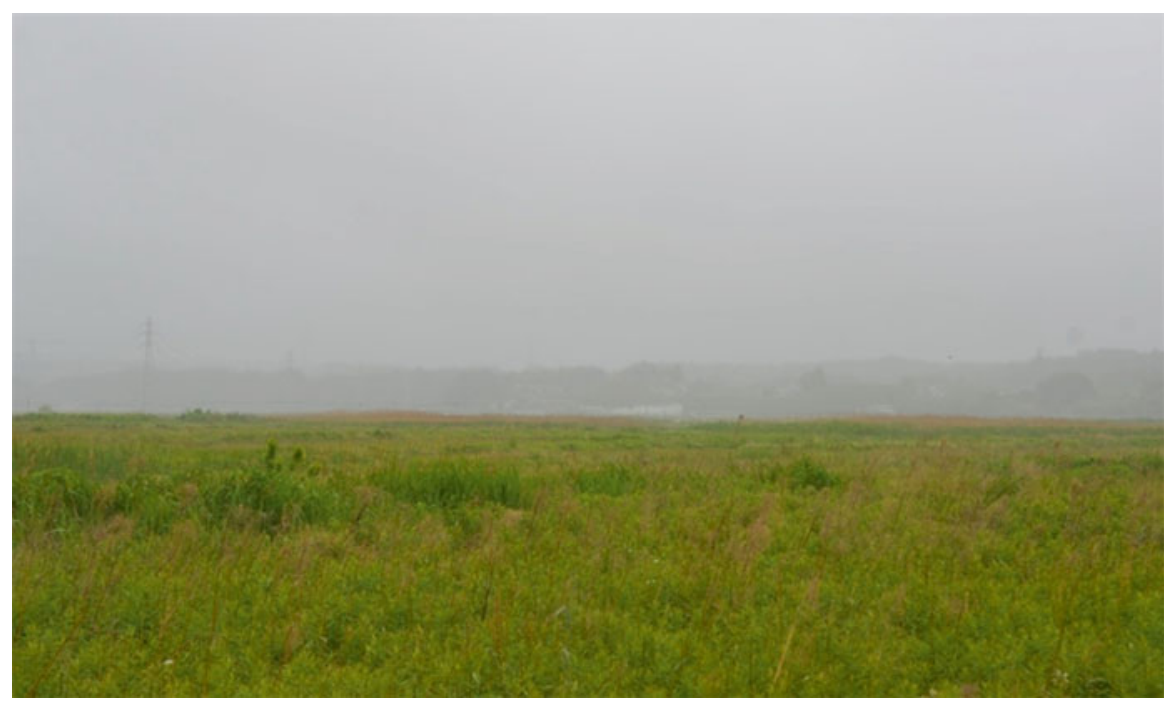

Fig. 10.3 Abandoned agricultural land in Namie

3. Unease about continued reputation-based damage. More than 3 years have passed since the explosions at Fukushima Daiichi Nuclear Power Station, and since then the Japanese public's concerns about the safety of Fukushima Prefecture's agricultural products have diminished, but the damage from negative reputation persists unabated. The key to recovering agriculture in Fukushima is to earn consumers' trust with regard to the safety of its agricultural products.

Having understood the full implications of these problems, we have been assisting in the recovery effort, guided by the following approaches.

1. Continue agricultural production in habitable areas without prohibiting crop planting. Otherwise, farmlands will rapidly go to ruin (Figs. 10.3 and 10.4).

2. Our consumer survey results, described later in this book, indicated that the way to ensure peace of mind among the public is not to simply lower the limit for radioactive content in Fukushima's agricultural produce. It is instead essential to ensure that none of Fukushima's agricultural produce distributed in the market ever contains any radionuclide detectable using standard detectors.

Our fundamental approaches to recovering agriculture and forestry in irradiated areas can be summarized thus. To put these principles into practice to bring about tangible recovery, we need to establish a system for each district to monitor radionuclides in individual parcels of cultivated land, matching decontamination measures to specific circumstances. We also need to select and produce safe crops and support the development of new agricultural businesses. 


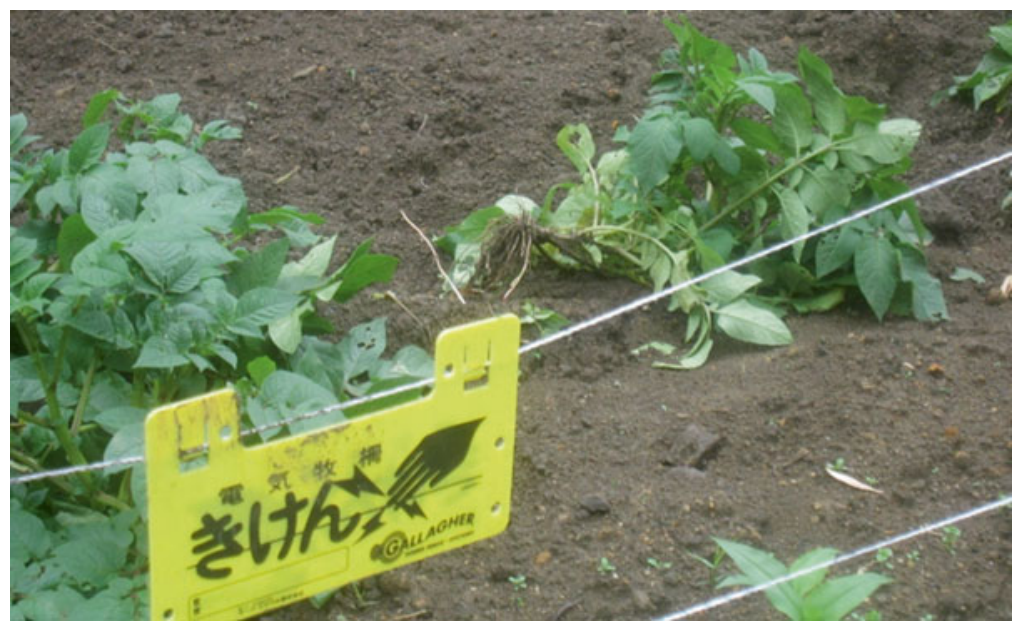

Fig. 10.4 Damage by wild boars in the Tamano district. (From blog of Ohashi industrial president)

\subsection{Description of the Location Used to Develop the Monitoring System: Soma's Tamano District}

\subsubsection{Overview of Tamano}

The Tamano district was incorporated into the city of Soma via municipal merger in 1954. Located between central Soma and the prefectural capital, Fukushima City, the Tamano district sits in a semi-mountainous area in the Abukuma Highlands, where the climate is comparatively cold. Tamano includes the four areas of Higashi Tamano, Nishi Tamano, Fukuryozen, and Ryozen. More than $60 \%$ of the residents make their living from farming, one of the district's main industries. Tamano's farming is diverse, including raising dairy and beef cattle as well as cultivation of rice, vegetables, and flowering plants. In recent years, the demographic changes that typify Japan's aging society have become more entrenched, with those over 65 years of age increasing and those under 15 years of age decreasing as a proportion of the farming household population. The problems presented by the farmers' advanced age, their lack of successors, and the resulting increase in abandoned land are now serious (Table 10.1).

\subsubsection{Damage to Local Agriculture from Radioactive Contamination}

The district of Tamano is located about 50-km from the Fukushima Daiichi Nuclear Power Station, next to the village of Iitate, which was designated an evacuation zone. Tamano's ambient radiation dose is therefore relatively high, although the 
Table 10.1 Trends and current circumstances in Tamano's agricultural industry

\begin{tabular}{l|r|r|c}
\hline & 1970 & 1990 & 2010 \\
\hline Total units (number) & 206 & 153 & 124 \\
\hline Non-farmers & 28 & 29 & 48 \\
\hline Farmers & 178 & 124 & 76 \\
\hline Sales farmers (number) & 178 & 124 & 47 \\
\hline Full-time farmer & 40 & 25 & 11 \\
\hline$\quad$ First kind part-time farmers & 112 & 17 & 8 \\
\hline Second-class part-time farmers & 26 & 82 & 28 \\
\hline Single management (number) & - & 64 & 32 \\
\hline Rice & - & 25 & 21 \\
\hline Dairy, beef cattle & - & 24 & 7 \\
\hline Poultry & - & 6 & 2 \\
\hline Other & - & 9 & 2 \\
\hline Quasi-single complex management (Number) & - & 30 & 11 \\
\hline Complex management (number) & - & 35 & 4 \\
\hline Percentage over 65 years old (\%) & - & 21.0 & 34.1 \\
\hline Percentage 15 years old (\%) & 27.4 & 18.9 & 2.3 \\
\hline Cultivated land area (ha) & 366 & 209 & 106 \\
\hline Abandoned farmland area (ha) & - & 19 & 176 \\
\hline
\end{tabular}

Source: Census of Agriculture

Table 10.2 Results of survey of ambient radiation doses in Soma

\begin{tabular}{l|l|l|l|l|l|l}
\hline \multirow{3}{*}{ Location } & 2011.00 & \multicolumn{3}{l}{2012.00} & 2013.00 & \\
\cline { 2 - 7 } & Soil & Pavement & Soil & Pavement & Soil & Pavement \\
\hline Soma city & 0.74 & 0.60 & 0.53 & 0.36 & 0.36 & 0.24 \\
\hline Nakamura & 0.49 & 0.36 & 0.32 & 0.23 & 0.23 & 0.16 \\
\hline Ono & 0.48 & 0.38 & 0.37 & 0.27 & 0.25 & 0.17 \\
\hline Iitoyo & 0.39 & 0.34 & 0.22 & 0.18 & 0.18 & 0.12 \\
\hline Hachiman & 0.72 & 0.57 & 0.51 & 0.34 & 0.36 & 0.22 \\
\hline Yamagami & 1.03 & 0.74 & 0.64 & 0.41 & 0.47 & 0.29 \\
\hline Nitaki & 0.55 & 0.46 & 0.37 & 0.27 & 0.29 & 0.20 \\
\hline Isobe & 0.38 & 0.28 & 0.27 & 0.19 & 0.20 & 0.14 \\
\hline Tamano & 1.88 & 1.70 & 1.56 & 1.00 & 0.93 & 0.60 \\
\hline
\end{tabular}

Source: "Information about radiation." Soma HP

Note: The number in the table is the average value; the unit is $\mu \mathrm{Sv} / \mathrm{h}$

annual cumulative dose remains below $20 \mathrm{mSv}$, so no evacuation order has been issued. Nonetheless, comparatively high radiation levels were detected in some areas and evacuation of the residents was seriously considered. The results of a grid survey of ambient radiation doses across Soma conducted by the city authorities showed that the average ambient dose in the Tamano district was highest immediately after the disaster at $1.88 \mu \mathrm{Sv} / \mathrm{h}$. The dose exhibited a downward trend subsequently, but 2.5 years after the disaster it still remains high at $0.93 \mu \mathrm{Sv} / \mathrm{h}$ (Table 10.2). 
The damage sustained by local agriculture from radioactive contamination was severe. Some of the rice produced in 2011 was found to exceed the newly set cesium limit of $100 \mathrm{~Bq} / \mathrm{kg}$. Although rice production is a key revenue source for farmers in the district, therefore they decided to voluntarily refrain from planting rice in fiscal 2012, and rice planting was postponed until fiscal 2013, when thorough decontamination would be complete.

Furthermore, radiation levels are also high in dairy farming pastures, and farmers are therefore prohibited from feeding the grass to their dairy cattle. To be able to continue farming they now rely on hay bought from other areas.

\subsection{Overview of the Radioactive Substance Monitoring System under Development}

As already described, it is clear that radioactive contamination is significantly inhibiting the recovery of the agriculture and forestry industries of Tamano. Thus, we are attempting to develop a practical monitoring system to ensure that safe agricultural commodities are produced and shipped.

In specific terms, this aim involved collecting and analyzing basic data to develop a monitoring system that could help us to decide decontamination measures, implement them, and evaluate their effects, for each parcel of farmland. Such basic data included the ambient radiation dose ( $1 \mathrm{~m}$ above ground), the soil surface dose $(1 \mathrm{~cm}$ from the ground), the concentration of radionuclide in the soil (at $0-5 \mathrm{~cm}$ and at 5-10 cm depths), the depth of the topsoil, and the soil characteristics (cationexchange capacity, exchangeable calcium, exchangeable potassium, available phosphoric acid, total nitrogen, soil acidity, etc.). We started the survey in June 2012, and by September we had collected basic data on 646 parcels (142 ha) of farmland including paddy fields, non-paddy arable fields, pastures, and greenhouses across Tamano. Table 10.3 and Figs.10.5 and 10.6 present the aim of surveying each item, the method used, and state of research; Table 10.4 presents the number of farmland parcels surveyed and their areas. In terms of area, paddy fields, non-paddy arable fields, and pastures accounted for 34 ha, 46 ha, and 62 ha, respectively, amounting to a total of 142 ha. In terms of numbers of parcels, paddy fields, non-paddy arable fields, and pastures accounted for 263 parcels, 278 parcels, and 105 parcels, respectively, making a total of 646 parcels. In the Higashi Tamano and Nishi Tamano areas, the parcels comprised mainly paddy fields and non-paddy arable fields, whereas in the Fukuryozen and Ryozen areas, the parcels comprised mainly pastures and non-paddy arable fields (Table 10.4). Table 10.5 shows part of the database created. 
Table 10.3 Items surveyed, aims, and methods

\begin{tabular}{|c|c|c|c|}
\hline \multicolumn{2}{|c|}{ Survey item } & \multirow{2}{*}{$\begin{array}{l}\text { Research objectives } \\
\text { owner, growers, land use } \\
\text { situation, and area in the } \\
\text { investigated land }\end{array}$} & \multirow{2}{*}{$\begin{array}{l}\begin{array}{l}\text { Investigation and measurement } \\
\text { methods }\end{array} \\
\text { Interviews with local leaders }\end{array}$} \\
\hline (1) & $\begin{array}{l}\text { Basic information } \\
\text { (owner name, } \\
\text { growers' name and } \\
\text { farmland area, etc. }\end{array}$ & & \\
\hline (2) & $\begin{array}{l}\text { Space dose of } 1 \mathrm{~m} \\
(\mu \mathrm{Sv} / \mathrm{h})\end{array}$ & $\begin{array}{l}\text { Grasp the external exposure } \\
\text { amount of farmer }\end{array}$ & $\begin{array}{l}\text { Using scintillation survey meter } \\
\text { TCS-172B, measured at } 1 \text { min at } \\
\text { a height of } 1 \mathrm{~m}\end{array}$ \\
\hline (3) & $\begin{array}{l}\text { Radiation dose of the } \\
\text { soil surface } 1 \mathrm{~cm} \\
(\mu \mathrm{Sv} / \mathrm{h}, \mathrm{CPM})\end{array}$ & $\begin{array}{l}\text { Grasp the radiation dose from } \\
\text { the soil }\end{array}$ & $\begin{array}{l}\text { Using a scintillation survey meter } \\
\text { TCS-172B-GM survey meter } \\
\text { TGS-146B, measured in } 1 \mathrm{~min} \text { at } \\
\text { the height } 1 \mathrm{~cm} \text { with lead } \\
\text { shielding }\end{array}$ \\
\hline (4) & $\begin{array}{l}\text { Depth of the } \\
\text { cultivated soil }(\mathrm{cm})\end{array}$ & $\begin{array}{l}\text { Selection of appropriate } \\
\text { decontamination method }\end{array}$ & $\begin{array}{l}\text { Measuring the hardness, the } \\
\text { depth of cultivated soil by use of } \\
\text { the soil penetration meter hand } \\
\text { auger }\end{array}$ \\
\hline (5) & $\begin{array}{l}\text { Radioactive material } \\
\text { concentration of each } \\
\text { depth of soil }(\mathrm{Bq} / \mathrm{kg})\end{array}$ & $\begin{array}{l}\text { Grasp the difference } \\
\text { radioactive material } \\
\text { concentration each soil depth }\end{array}$ & $\begin{array}{l}\text { The collected samples the soil } \\
0-5 \mathrm{~cm}, 5-10 \mathrm{~cm} \text {, measured at } \\
3 \text { min using an auto gamma } \\
\text { system AccuFLEX } 7010\end{array}$ \\
\hline (6) & Soil nutritional status & $\begin{array}{l}\text { Design the fertilization after } \\
\text { decontamination (required } \\
\text { nutrition, corrosion content, } \\
\text { cation-exchange capacity, } \\
\text { etc.) }\end{array}$ & $\begin{array}{l}\text { Measured collecting samples of } \\
\text { soil depth of } 15 \mathrm{~cm}\end{array}$ \\
\hline
\end{tabular}

\subsection{Results of Radioactive Substance Monitoring and Its Practical Uses}

\subsubsection{Monitoring Results}

\subsubsection{Concentrations of Radionuclide in Farmlands and Efficacy of Decontamination}

\section{Characteristics of Radioactive Substance Concentration in Farmlands}

Table 10.6 shows the results of surveying ambient radiation doses and radioactive contamination levels in the topsoil of Tamano's farmlands, categorized by location and land type. For Tamano as a whole, the average ambient dose at a height of $1 \mathrm{~m}$ is $1 \mu \mathrm{Sv} / \mathrm{h}$ and the surface radiation dose is $0.34 \mu \mathrm{Sv} / \mathrm{h}$. The depth of the farmland topsoil is $17 \mathrm{~cm}$, and the concentration of radionuclide in the soil varies from 2,700 to $5,900 \mathrm{~Bq} / \mathrm{kg}$. Among the various locations, the ambient dose is highest in Ryozen, 


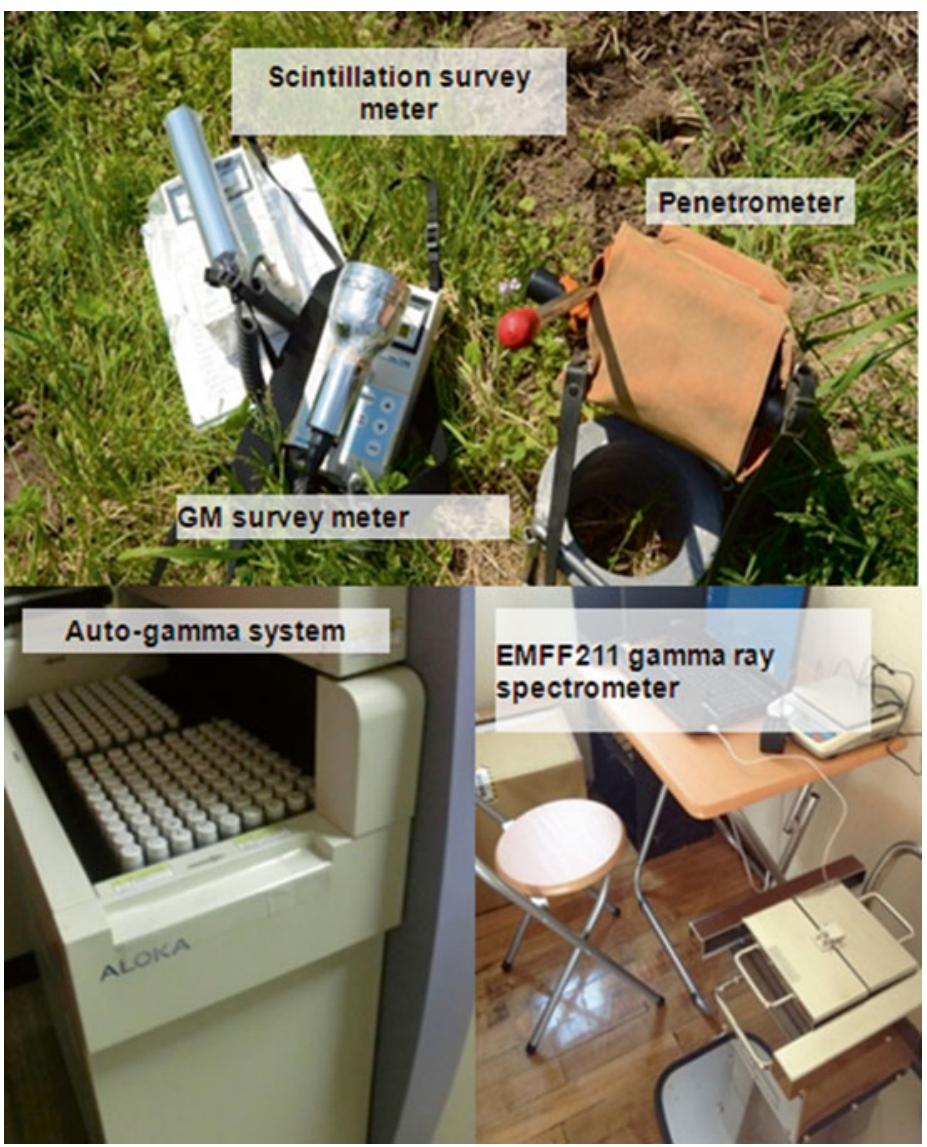

Fig. 10.5 Devices to measure ambient radiation doses and radionuclides

at $1.15 \mu \mathrm{Sv} / \mathrm{h}$, followed by Nishi Tamano, Fukuryozen, and Higashi Tamano. The surface radiation doses are low in Higashi Tamano and Nishi Tamano, but they are relatively high in Ryozen and Fukuryozen. The depth of farmland topsoil is 19-21 cm in Higashi Tamano and Nishi Tamano and 9-10 cm in Ryozen and Fukuryozen.

Turning to the concentrations of radionuclide within the soil itself, in Nishi Tamano and Ryozen, as well as in the Tamano district as a whole, the levels in the lower layer 5-10 cm below the surface are about half the levels in the upper layer 0-5 cm below the surface. In Higashi Tamano, on the other hand, there is a limited difference in the concentrations between the upper and lower layers, which can be attributed to the effects of incorporating rice straw into the soil and plowing in fiscal 2011. Meanwhile, in Fukuryozen, where the concentration of radionuclide is much higher in the upper layer, the topsoil is shallow, and a large volume of radionuclide was deposited on the upper layer in the pastures, which are not usually plowed. 

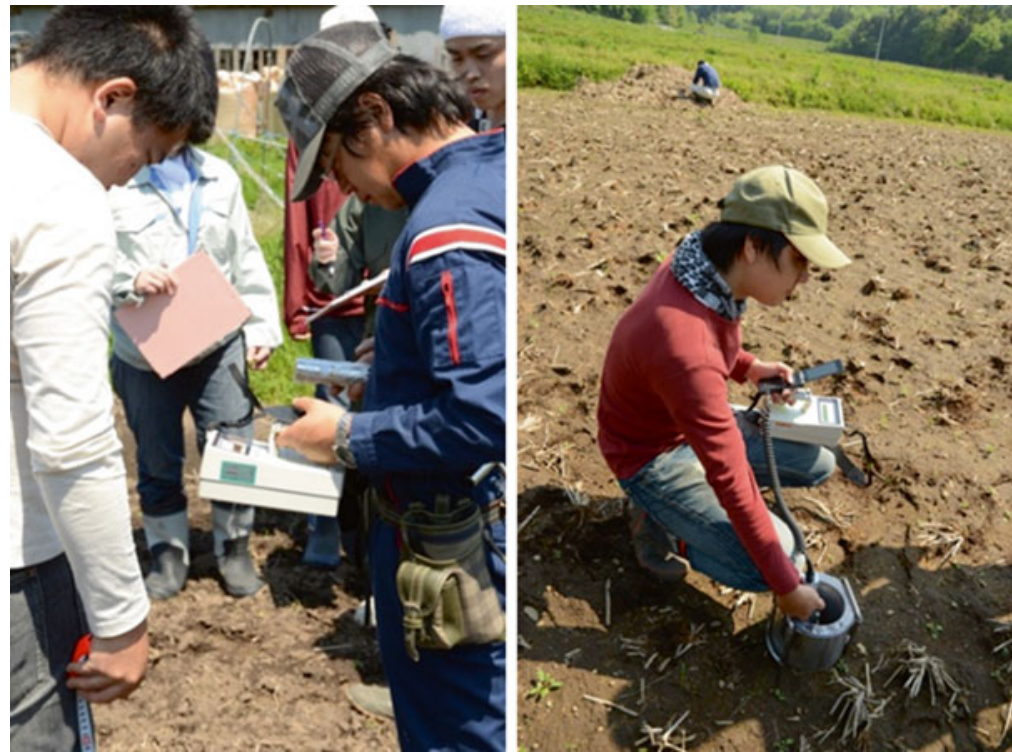

Fig. 10.6 Measuring ambient radiation doses

Table 10.4 Number of parcels and areas of farmland surveyed

\begin{tabular}{l|l|l|l|l|l|l}
\hline \multirow{2}{*}{ Area } & Total & $\begin{array}{l}\text { Higashi } \\
\text { tamano }\end{array}$ & $\begin{array}{l}\text { Nishi } \\
\text { tamano }\end{array}$ & Fukuryozen & Ryouzen \\
\hline \multicolumn{2}{l}{ Number of growers (person) } & 134 & 35 & 61 & 21 & 21 \\
\hline $\begin{array}{l}\text { Investigated } \\
\text { farmland }\end{array}$ & $\begin{array}{l}\text { Field number } \\
\text { (plot) }\end{array}$ & 646 & 167 & 320 & 103 & 56 \\
\cline { 2 - 7 } & Area (ha) & 142.42 & 44.24 & 46.95 & 44.11 & 7.12 \\
\hline Paddy & $\begin{array}{l}\text { Field number } \\
\text { (plot) }\end{array}$ & 263 & 92 & 161 & 2 & 8 \\
\cline { 2 - 8 } & Area (ha) & 34.3 & 13.9 & 19.1 & 0.1 & 1.2 \\
\hline \multirow{2}{*}{ Field } & $\begin{array}{l}\text { Field number } \\
\text { (plot) }\end{array}$ & 278 & 65 & 136 & 41 & 36 \\
\cline { 2 - 8 } & Area (ha) & 46.1 & 27.5 & 12.6 & 3.6 & 2.4 \\
\hline Pasture & $\begin{array}{l}\text { Field number } \\
\text { (plot) }\end{array}$ & 105 & 10 & 23 & 60 & 12 \\
\cline { 2 - 7 } & Area (ha) & 62.1 & 2.8 & 15.3 & 40.4 & 3.5 \\
\hline
\end{tabular}

In terms of land type, the pastures register a high ambient radiation dose of $1.19 \mu \mathrm{Sv} / \mathrm{h}$, compared to an ambient dose of $0.94-0.97 \mu \mathrm{Sv} / \mathrm{h}$ in paddy fields and non-paddy arable fields. In such paddies and arable fields the concentration of radionuclide in the soil's lower layer is about half that in the upper layer. In the pastures, however, an extremely low level in the lower layer contrasts with an extremely high level in the upper layer. The farmlands surveyed also include many 


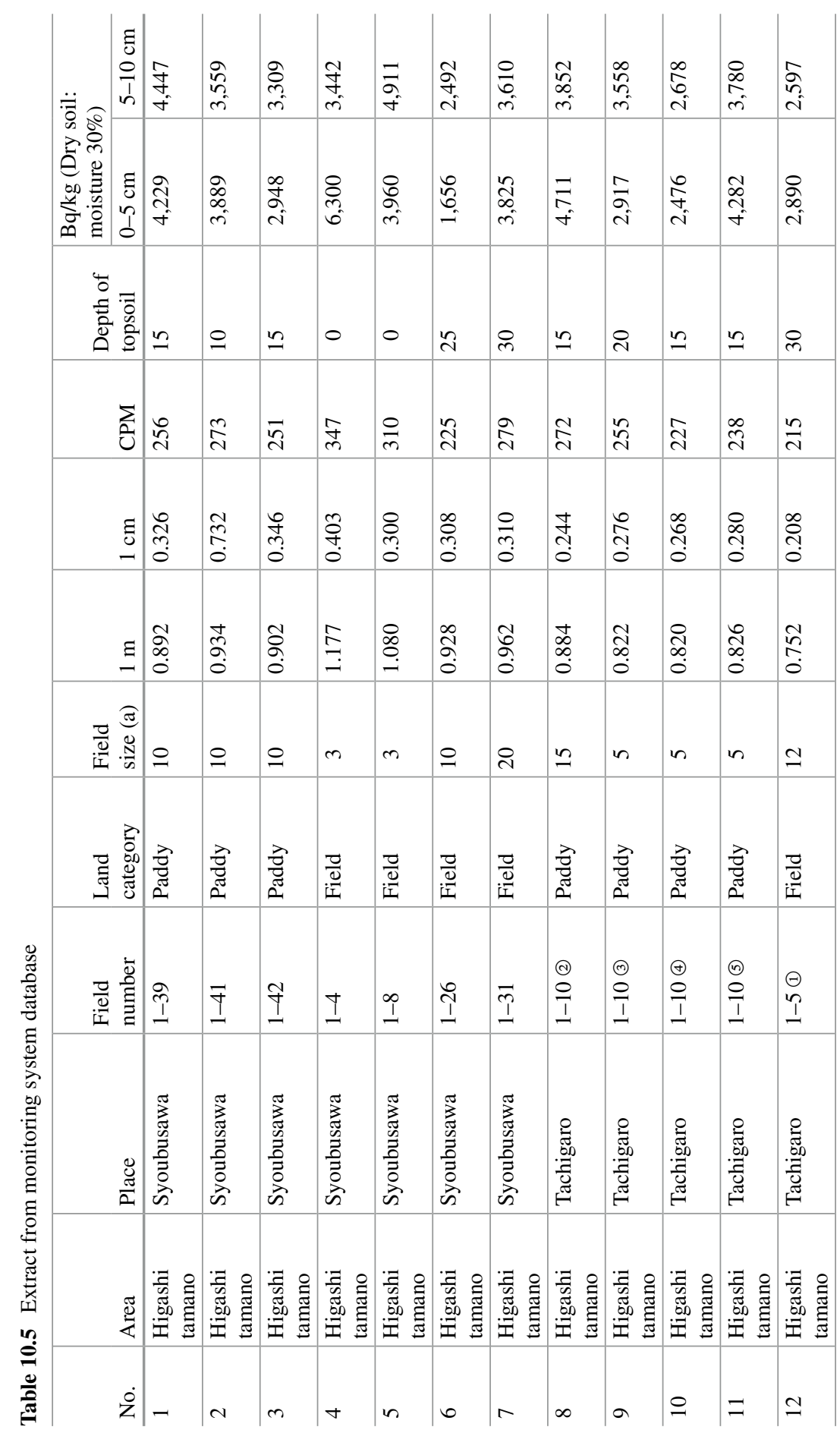




\begin{tabular}{|c|c|c|c|c|c|c|c|c|c|c|c|c|}
\hline 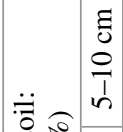 & $\begin{array}{l}\hat{a} \\
\infty \\
i \\
i\end{array}$ & ষ & & & $\begin{array}{l}\mathcal{U} \\
\infty \\
+ \\
+\end{array}$ & $\begin{array}{l}m \\
\infty \\
\infty \\
\infty\end{array}$ & ڤ̊ & $\mathscr{6}$ & $\begin{array}{l}\stackrel{2}{2} \\
\text { m. } \\
m\end{array}$ & $\vec{\delta}$ & $\begin{array}{l}\hat{s} \\
n \\
n \\
n\end{array}$ & $\frac{\vec{I}}{m}$ \\
\hline 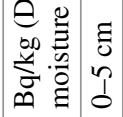 & $\begin{array}{l}8 \\
n \\
m \\
m\end{array}$ & $\begin{array}{l}\bar{\infty} \\
\dot{0} \\
\dot{\sim}\end{array}$ & & & 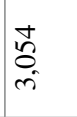 & 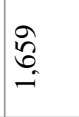 & $\stackrel{m}{\stackrel{n}{\simeq}}$ & $\underset{\infty}{\stackrel{\infty}{+}}$ & $\frac{\hat{m}}{m}$ & 足 & $\begin{array}{l}\stackrel{2}{\infty} \\
\text { ले }\end{array}$ & $\begin{array}{l}\text { त̂ } \\
\text { ñ }\end{array}$ \\
\hline 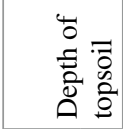 & 用 & & 0 & 0 & 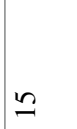 & ల & in & $\simeq$ & ㄱ. & $\approx$ & $n$ & ¿i \\
\hline$\sum_{0}$ & 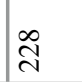 & $\begin{array}{l}\infty \\
i n\end{array}$ & $\stackrel{0}{\sim}$ & ते & $\overrightarrow{\mathrm{N}}$ & $\underset{t}{\mathbb{t}}$ & ণ্ & $\curvearrowleft$ & $\infty$ & $\stackrel{ \pm}{n}$ & $\Omega$ & $\underset{\sim}{\widetilde{N}}$ \\
\hline 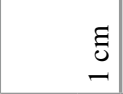 & 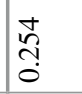 & $\begin{array}{l}\tilde{n} \\
\tilde{n} \\
0 \\
0\end{array}$ & $\frac{0}{1 !}$ & 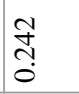 & $\begin{array}{l} \pm \\
\infty \\
ٍ \\
0\end{array}$ & $\stackrel{\stackrel{J}{I}}{\stackrel{0}{0}}$ & 足 & $\stackrel{\vec{m}}{\overrightarrow{0}}$ & 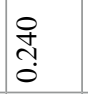 & $\stackrel{\infty}{m}$ & $\begin{array}{l}0 \\
\infty \\
1 \\
0\end{array}$ & 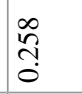 \\
\hline$\Xi$ & $\frac{\dot{v}}{\stackrel{0}{0}}$ & 导 & $\stackrel{\infty}{\infty}$ & 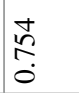 & $\begin{array}{l}0 \\
\\
\end{array}$ & \& & ָ̃ & $\underset{\substack{f \\
\hdashline}}{0}$ & तु & $\begin{array}{l}\infty \\
\infty \\
n \\
0 \\
0\end{array}$ & 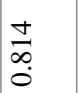 & $\begin{array}{l}\infty \\
\stackrel{2}{0} \\
0\end{array}$ \\
\hline 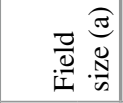 & 1 & 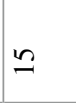 & 8 & 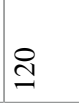 & $m$ & 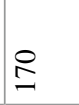 & 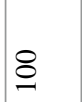 & 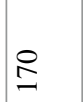 & 1 & 1 & 1 & 1 \\
\hline 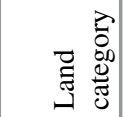 & $\frac{7}{0}$ & 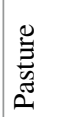 & $\frac{\overline{0}}{20}$ & $\frac{7}{0}$ & $\frac{\overrightarrow{0}}{\stackrel{0}{I}}$ & $\frac{\overrightarrow{0}}{\frac{0}{2}}$ & $\frac{\pi}{\frac{0}{2}}$ & $\frac{\overrightarrow{0}}{0}$ & $\frac{\overrightarrow{0}}{2}$ & $\frac{\partial}{20}$ & $\frac{\overrightarrow{0}}{\frac{0}{2}}$ & $\frac{\partial}{0}$ \\
\hline 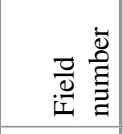 & $\begin{array}{l}0 \\
1 \\
1 \\
-1\end{array}$ & $\begin{array}{l}\Theta \\
\stackrel{\varrho}{I} \\
I\end{array}$ & & $\frac{i}{i}$ & $\stackrel{\sim}{\circ}$ & $\begin{array}{l}\overline{1} \\
\infty \\
\sim\end{array}$ & নे & $\begin{array}{l}\Theta \\
\stackrel{\Gamma}{ }\end{array}$ & (a) & $\begin{array}{l}\text { () } \\
\text { ᄋ }\end{array}$ & @ & (1) \\
\hline$\frac{\mathscr{g}}{2}$ & 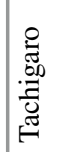 & 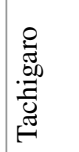 & 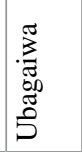 & 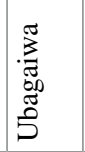 & 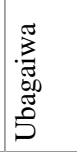 & 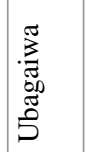 & 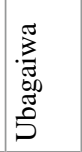 & 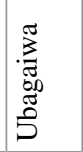 & 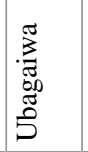 & 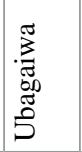 & 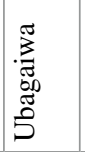 & 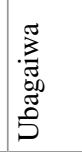 \\
\hline 莺 & 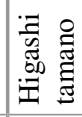 & 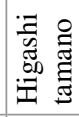 & 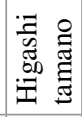 & 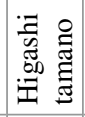 & 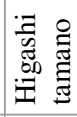 & 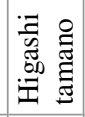 & 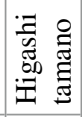 & 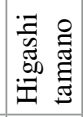 & 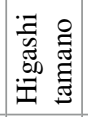 & 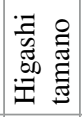 & 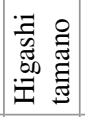 & 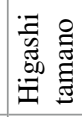 \\
\hline$\dot{z}$ & $\cong$ & \pm & $\stackrel{2}{2}$ & $\stackrel{0}{0}$ & 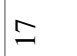 & $\stackrel{\infty}{-}$ & $\because$ & సి & $\bar{\sim}$ & $\tilde{N}$ & $\tilde{\lambda}$ & $\stackrel{d}{\sim}$ \\
\hline
\end{tabular}




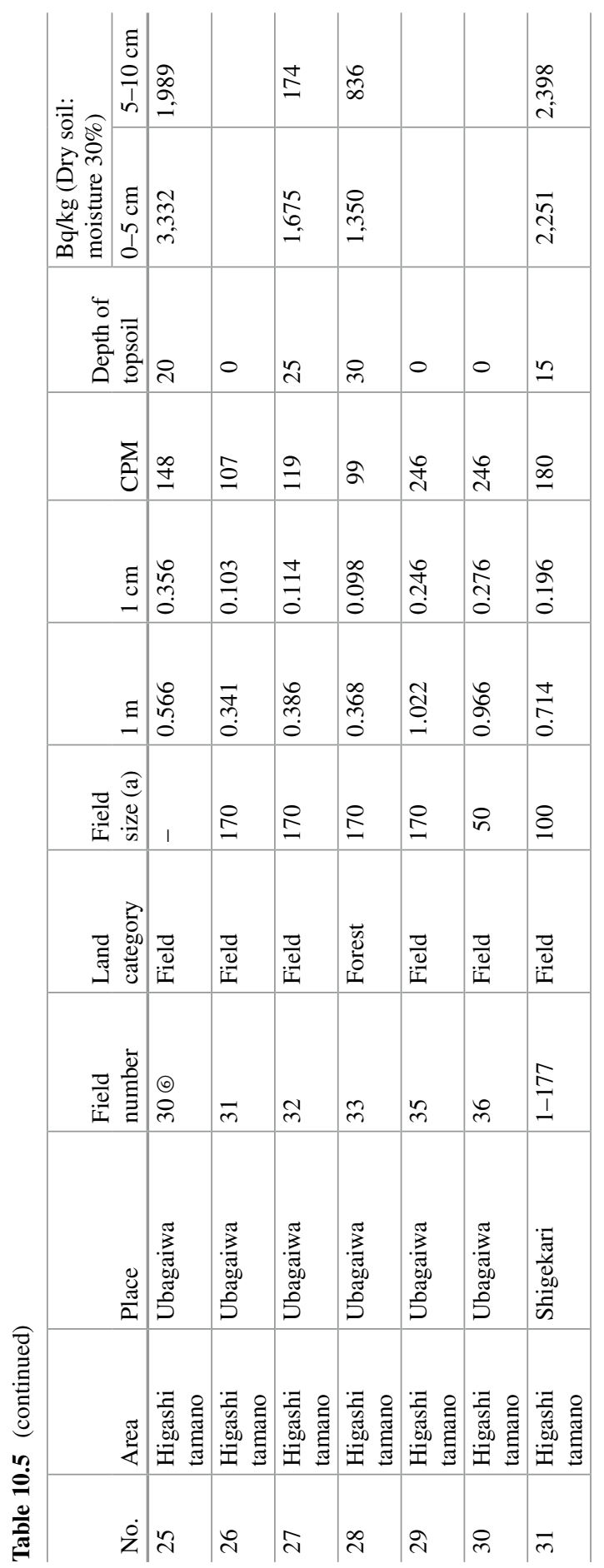


Table 10.6 Ambient radiation doses of farmlands and concentrations of radionuclide in the soil

\begin{tabular}{l|l|l|l|l|l|l}
\hline \multicolumn{2}{c|}{} & $\begin{array}{l}\text { Air dose } \\
(\text { ground } \\
1 \mathrm{~m})\end{array}$ & $\begin{array}{l}\text { Soil surface } \\
\text { dose }(1 \mathrm{~cm})\end{array}$ & $\begin{array}{l}\text { Depth of } \\
\text { topsoil }\end{array}$ & \multicolumn{2}{|l}{$\begin{array}{l}\text { Concentration of } \\
\text { radioactive substances } \\
\text { in soil }(\mathrm{Bq} / \mathrm{kg})\end{array}$} \\
\cline { 3 - 8 } & $(\mu \mathrm{SV} / \mathrm{h})$ & $(\mu \mathrm{SV} / \mathrm{h})$ & $(\mathrm{cm})$ & $0-5 \mathrm{~cm}$ & $5-10 \mathrm{~cm}$ \\
\hline \multirow{3}{*}{ By area } & Average of area & 1.00 & 0.34 & 17 & 5,933 & 2,708 \\
\cline { 2 - 8 } & Higashi Tamano & 0.86 & 0.26 & 19 & 4,045 & 3,233 \\
\cline { 2 - 8 } & Nishi Tamano & 1.06 & 0.28 & 21 & 5,876 & 2,842 \\
\cline { 2 - 8 } & Fukuryozen & 0.98 & 0.68 & 10 & 5,706 & 1,270 \\
\cline { 2 - 8 } & Ryozen & 1.15 & 0.33 & 9 & 7,968 & 3,063 \\
\hline \multirow{2}{*}{$\begin{array}{l}\text { Type of } \\
\text { land use }\end{array}$} & Paddy & 0.94 & 0.25 & 21 & 5,008 & 2,757 \\
\cline { 2 - 8 } & Field & 0.97 & 0.27 & 14 & 5,113 & 3,330 \\
\cline { 2 - 8 } & $\begin{array}{l}\text { Meadow- } \\
\text { pastureland }\end{array}$ & 1.19 & 0.70 & 7 & 8,715 & 1,001 \\
\hline
\end{tabular}

Note: Concentration of radionuclide is a converted value of $30 \%$ moisture

hotspots with a high concentration of radionuclide in their upper layer, exceeding $10,000 \mathrm{~Bq} / \mathrm{kg}$, particularly in pastures, as well as in unplowed paddy fields and nonpaddy arable fields. It is essential to establish a risk management system using radioactive contamination maps in these areas.

\section{Decontamination of Paddy Fields and Its Efficacy}

These survey results were used to consider possible decontamination measures for the farmlands in Tamano. The specific measures chosen for paddy fields and nonpaddy arable fields involved deep plowing and scattering soil improvement agents. In pastures, on the other hand, the shallow topsoil meant that just a thin layer of surface soil would be removed, with soil brought in from other areas where necessary. Decontamination work started in Tamano's paddy fields at the end of November 2012. However, the arable soil in Tamano's paddy fields is generally not very deep, and many areas contain rocks underneath the soil, so the work was undertaken carefully at 1.5 times the normal depth, one paddy at a time. Large tractors were not used to avoid damaging the plow sole. Cesium absorption was inhibited by scattering $200 \mathrm{~kg}$ zeolite and $50 \mathrm{~kg}$ potassium chloride per 10 ares.

In non-paddy arable fields, individual farmers undertook decontamination and started planting crops. Decontamination of pastures started in July 2013, and sowing of grass is planned for that fall.

We first evaluated the efficacy of Tamano's paddy field decontamination in May 2013. The survey results are compiled in Table 10.7. Looking first at the ambient radiation dose before decontamination (in July 2012) and after decontamination, we find that it dropped by about $0.1 \mu \mathrm{Sv} / \mathrm{h}$ from 0.83 to $0.73 \mu \mathrm{Sv} / \mathrm{h}$ in Higashi Tamano and by about $0.15 \mu \mathrm{Sv} / \mathrm{h}$ from 1.01 to $0.86 \mu \mathrm{Sv} / \mathrm{h}$ in Nishi Tamano. However, it proved impossible to meet the Japanese Ministry of the Environment's target of 
Table 10.7 Ambient radiation doses and concentrations of radionuclide in paddy field soil in Tamano before and after decontamination

\begin{tabular}{|c|c|c|c|c|c|}
\hline \multirow{2}{*}{$\begin{array}{l}\text { Before decontamination } \\
\text { (2012) }\end{array}$} & \multirow{2}{*}{$\begin{array}{l}\text { Air dose } \\
(\mu \mathrm{Sv} / \mathrm{h})\end{array}$} & \multicolumn{4}{|c|}{$\begin{array}{l}\text { Concentration of soil radioactive substances } \\
(\mathrm{Bq} / \mathrm{kg})\end{array}$} \\
\hline & & \multicolumn{2}{|c|}{$0-5 \mathrm{~cm}$} & \multicolumn{2}{|c|}{$5-10 \mathrm{~cm}$} \\
\hline Higashitamano & 0.83 & \multicolumn{2}{|l|}{4,050} & \multicolumn{2}{|l|}{3,312} \\
\hline Nishitamano & 1.01 & \multicolumn{2}{|l|}{5,576} & \multicolumn{2}{|l|}{2,423} \\
\hline \multirow[t]{2}{*}{ After decontamination 2013} & \multirow[t]{2}{*}{$\begin{array}{l}\text { Air dose } \\
(\mu \mathrm{Sv} / \mathrm{h})\end{array}$} & \multicolumn{4}{|c|}{$\begin{array}{l}\text { Concentration of soil radioactive substances } \\
(\mathrm{Bq} / \mathrm{kg})\end{array}$} \\
\hline & & Cs total & Cs-137 & Cs-134 & K-40 \\
\hline Higashitamano & 0.73 & 3,213 & 2,069 & 1,144 & 799 \\
\hline Nishitamano & 0.86 & 4,107 & 2,651 & 1,456 & 1,010 \\
\hline
\end{tabular}

Note: Concentration of radionuclide is a converted value of $30 \%$ moisture

lowering the ambient radiation dose by half, indicating that it is difficult to lower ambient radiation doses in semi-mountainous areas surrounded by mountain forests.

Moving on to changes in the concentrations of radionuclide in the soil, in 2012 we measured the soil contamination levels in the paddy fields at two different depths, 0-5 cm and 5-10 cm. In fiscal 2013, however, the paddies had been deep plowed during the decontamination process, so we took soil samples for measurement without making distinctions based on depth. As a result of the soil having been mixed, the total cesium concentration was found to have decreased by about $1,000 \mathrm{~Bq} / \mathrm{kg}$ compared to the concentration in the $0-5 \mathrm{~cm}$ layer in 2012 .

Figure 10.7 summarizes the efficacy of decontamination in each parcel of paddy field in the form of a map. As the map clearly shows, cesium concentration in many of the paddies decreased. However, upon closer examination, there are also some paddies in which the concentration did not decrease, indicating that it is essential to investigate why this occurred and to study how to inhibit absorption of radionuclide.

\section{Decontamination of Meadows and Grazing Land and Its Efficacy}

Radionuclide in pastures are accumulated primarily on the surface. To decide how to decontaminate the pastures, we examined data we collected for monitoring system development purposes. The data included the depths of the surface soil, the concentrations of radionuclide, and the ambient radiation doses for each parcel of meadowland and grazing land (Table 10.8).

The specific decontamination method we selected was use of a backhoe to scrape off $4 \mathrm{~cm}$ of surface soil in meadows and grazing land. This decontamination work is currently under way, with completion scheduled for the end of October 2013. Although the efficacy of the decontamination will be evaluated in detail later, the concentrations of radionuclide measured in some of the meadows and grazing land 


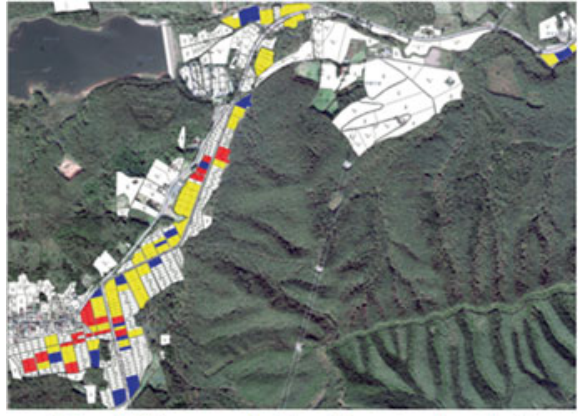

Higashi Tamano (before decontamination)

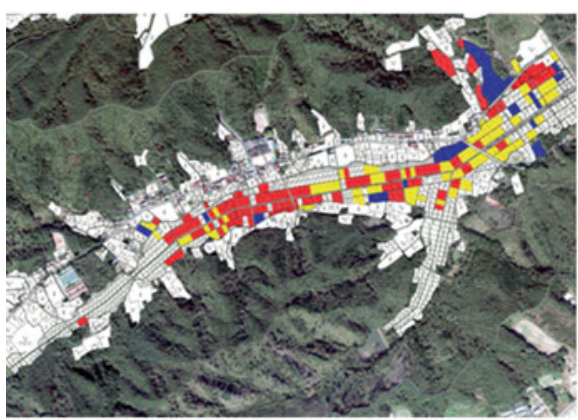

Nishi Tamano (before decontamination)

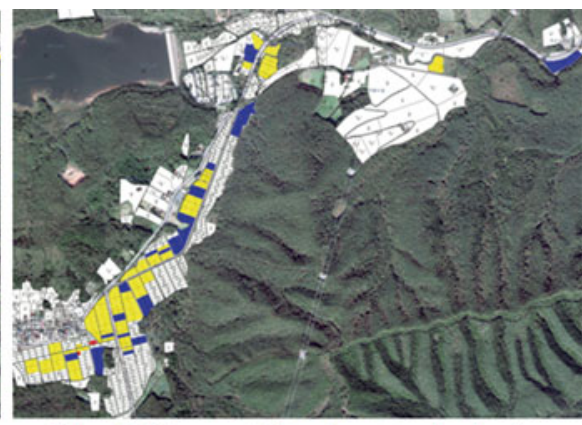

Higashi Tamano (after decontamination)

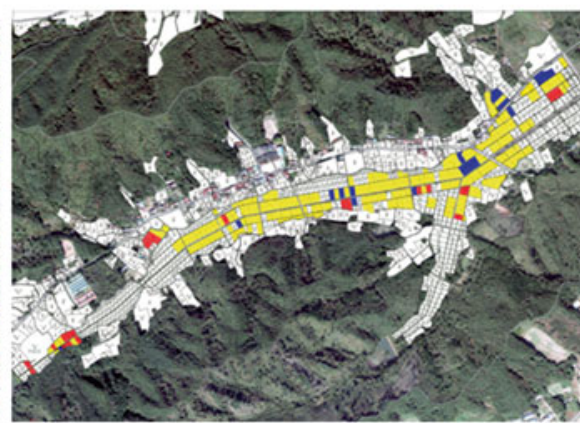

Nishi Tamano (after decontamination)

Fig. 10.7 Partial map of radioactive contamination in paddy field soil in Higashi Tamano and Nishi Tamano before and after decontamination. Note: Colors in the figure are classified by concentration of radioactive soil: blue, less than $3,000 \mathrm{~Bq} / \mathrm{kg}$; yellow, 3,000-4,999 Bq/kg; red, more than $5,000 \mathrm{~Bq} / \mathrm{kg}$

Table 10.8 Ambient radiation doses and concentrations of radionuclide in meadows and grazing land (2012)

\begin{tabular}{l|l|l|c}
\hline \multirow{2}{*}{ Location } & \multicolumn{2}{|l}{$\begin{array}{l}\text { Concentration of soil radioactive substances } \\
(\mathrm{Bq} / \mathrm{kg})\end{array}$} \\
\cline { 2 - 4 } & Air dose $(\mu \mathrm{Sv} / \mathrm{h})$ & $0-5 \mathrm{~cm}$ & $5-10 \mathrm{~cm}$ \\
\hline Nishitamano & 1.26 & 6,769 & 1,021 \\
\hline Fukuryozen & 1.09 & 8,604 & 895 \\
\hline Ryozen & 1.31 & 9,480 & 2,279 \\
\hline
\end{tabular}

Note: Concentration of radionuclide is a converted value of $30 \%$ moisture

that have already been decontaminated were found to have dropped to one-tenth of their original levels.

However, the migration of radionuclide from the soil to the grass remains an issue. We investigated the migration of radionuclide to the first grass of 2013 for each parcel of meadow and grazing land. As shown in Table 10.9, the migration coefficient differed substantially for each location. In research conducted previously, 
Table 10.9 Concentrations of radionuclide in meadows and grazing lands and coefficients of migration to grass

\begin{tabular}{l|l|l|l|l|l}
\hline \multirow{2}{*}{$\begin{array}{l}\text { Location } \\
\text { Air dose } \\
(\mu \mathrm{Sv} / \mathrm{h})\end{array}$} & $\begin{array}{l}\text { Concentration of soil radioactive substances } \\
(\mathrm{Bq} / \mathrm{kg})\end{array}$ & Cs total & Cs-137 & Cs-134 & K40 \\
\hline Nishitamano & 1.57 & 5,858 & 3,776 & 2,081 & 1,339 \\
\hline Fukuryozen & 0.94 & 5,953 & 3,836 & 2,117 & 1,438 \\
\hline Ryozen & 1.30 & 11,922 & 7,732 & 4,190 & 2,713 \\
\hline & Concentration of soil radioactive substances $(\mathrm{Bq} / \mathrm{kg})$ & Transition \\
\cline { 2 - 6 } & Cs total & Cs-137 & Cs-134 & K40efficient \\
\hline Nishitamano & 67 & 38 & 29 & 158 & 0.014 \\
\hline Fukuryozen & 239 & 147 & 92 & 217 & 0.042 \\
\hline Ryozen & 708 & 445 & 263 & 325 & 0.058 \\
\hline
\end{tabular}

Note: Concentration of radionuclide is a converted value of $30 \%$ moisture

the generally accepted coefficient for migration of radionuclide to grass had been 0.045. The discrepancies that appeared in our research could be explained by differences in soil types, grasses planted, and manure used in the meadows and grazing lands.

\subsection{Future Issues and Trends in the Use of Radioactive Substance Monitoring Systems}

The monitoring system we developed has been actively used in decontaminating farmlands. Decontamination of paddy fields has already been completed, and the decontamination of meadows and grazing lands is currently in progress. In addition to its use in publicly funded decontamination of farmlands, the monitoring system has also been actively used by individual farmers, who familiarized themselves with the concentrations of radionuclide in their own farmlands to adopt their own countermeasures. We therefore provided the data for each parcel of farmland in the form of feedback to all the owners and cultivators. In addition, the map of radioactive substance concentrations in farmlands across the entire area was provided to the chiefs of the Higashi Tamano, Nishi Tamano, Ryozen, and Fukuryozen areas, and was also made available to all residents by displaying it at assembly halls and other public buildings in each area. Ideally, the monitoring system should be used by the farmers themselves to monitor radionuclide in each area as a whole. We therefore need to structure the system so that the farmers can measure such substances simply, 
rapidly, and accurately. Therefore, we estimated the cost of the monitoring system development (Lurhathaiopath et al. 2014) and proposed the direction of agricultural policy in the radioactive contamination area.

Open Access This chapter is distributed under the terms of the Creative Commons Attribution Noncommercial License, which permits any noncommercial use, distribution, and reproduction in any medium, provided the original author(s) and source are credited.

\section{References}

Lurhathaiopath P, Kawano Y, Monma T (2014) Farming reconstruction support and the development of each farmland radioactive materials monitoring system. J Farm Manag Soc Jpn 52(1,2):67-72 (in Japanese)

Monma T (2014) Radioactive contamination and agricultural policy. J Rural Soc Econ 32(1):1524 (in Japanese) 